\title{
Understanding of catalytic ROS generation from defect-rich graphene quantum-dots for therapeutic effects in tumor microenvironment
}

\author{
Xichu Wang, Chuangang Hu, Zi Gu ${ }^{*+}$ (D) and Liming Dai ${ }^{*+}$
}

\begin{abstract}
Owing to their low cost, high catalytic efficiency and biocompatibility, carbon-based metal-free catalysts (C-MFCs) have attracted intense interest for various applications, ranging from energy through environmental to biomedical technologies. While considerable effort and progress have been made in mechanistic understanding of C-MFCs for non-biomedical applications, their catalytic mechanism for therapeutic effects has rarely been investigated. In this study, defect-rich graphene quantum dots (GQDs) were developed as C-MFCs for efficient ROS generation, specifically in the $\mathrm{H}_{2} \mathrm{O}_{2}$-rich tumor microenvironment to cause multi-level damages of subcellular components (even in nuclei). While a desirable anti-cancer performance was achieved, the catalytic performance was found to strongly depend on the defect density. It is for the first time that the defect-induced catalytic generation of ROS by C-MFCs in the tumor microenvironment was demonstrated and the associated catalytic mechanism was elucidated. This work opens a new avenue for the development of safe and efficient catalytic nanomedicine.
\end{abstract}

Keywords: Carbon-based metal-free catalyst, Graphene quantum dot, Defect, Reactive oxygen species, Tumor microenvironment

\section{Introduction}

Reactive Oxygen species (ROS) play an important role in maintaining biological functions. Cells inherently produce ROS that serves as cell signaling molecules for normal biological processes [1]. On the other hand, excessive ROS could induce oxidative stress to damage lipids, proteins and DNA, leading to apoptosis [1-4], necroptosis [2], and autophagic cell death [3,5]. Thus, ROS-induced cell death could be one of the attractive options for cancer therapy if the cancer cell-specific ROS generation can be achieved. Nevertheless, the tumor microenvironment

*Correspondence: zi.gu1@unsw.edu.au; I.dai@unsw.edu.au

${ }^{\dagger} \mathrm{Zi}$ Gu and Liming Dai joint senior authors

Australian Carbon Materials Centre (A-CMC), School of Chemical

Engineering, University of New South Wales, Sydney, NSW 2052, Australia
(TME) is a unique protective ecosystem that helps cancer cells to thrive [6], and a high level of hydrogen peroxide $\left(\mathrm{H}_{2} \mathrm{O}_{2}\right)$ in TME has been demonstrated to promote tumor growth through apoptosis resistance, DNA alteration, and cell proliferation angiogenesis [7]. In the presence of an appropriate catalyst, hydrogen peroxide can be used for the catalytic generation of ROS, which, if excessively generated in a TME, could be used to kill cancer cells. Therefore, the catalyst is a key for ROS-induced cancer cell death.

By making redox reaction catalysts respond to specific biological milieu to achieve therapeutic effects, catalytic nanomaterials hold great promise to harness redox reactions for biochemical applications. In this context, catalytic nanomaterials have been used to mediate reactions to convert non-therapeutic compounds in the original author(s) and the source, provide a link to the Creative Commons licence, and indicate if changes were made. The images or other third party material in this article are included in the article's Creative Commons licence, unless indicated otherwise in a credit line to the material. If material is not included in the article's Creative Commons licence and your intended use is not permitted by statutory regulation or exceeds the permitted use, you will need to obtain permission directly from the copyright holder. To view a copy of this licence, visit http://creativecommons.org/licenses/by/4.0/. The Creative Commons Public Domain Dedication waiver (http://creativeco mmons.org/publicdomain/zero/1.0/) applies to the data made available in this article, unless otherwise stated in a credit line to the data. 
TME to therapeutic agents for specifically killing tumor cells. Recently, nanoparticles such as black phoshoruse nanosheet [8] and nanodots [9] were proposed to selectively induce ROS mediated cell death. In particular, iron nanoparticles [10-12] were used to disproportionate $\mathrm{H}_{2} \mathrm{O}_{2}$ in the TME to cytotoxic hydroxyl radicals $(\cdot \mathrm{OH})$ via Fenton(-like) reactions. Other nanoparticles, containing $\mathrm{Mn}, \mathrm{Co}, \mathrm{Cu}$, or Ag element [6,13-16], have also been demonstrated to act as nanozyme agents for inhibiting tumor growth. However, metal-containing nanoparticles with a strong chelation ability could interfere with the functionalities of biological molecules and/or tissues to inevitably expose biosafety risks [5]. By contrast, metalfree carbon-based catalysts (C-MFCs) are biocompatible, cost-effective, and multifunctional [17].

Since the discovery of nitrogen $(\mathrm{N})$-doped carbon nanotube catalyst as the first C-MFC for electrocatalytic oxygen reduction reaction (ORR) in 2009 [18], C-MFCs have been widely explored as efficient, low-cost alternatives to metal-based catalysts for energy, environmental and biomedical applications [19]. Of particular interest, $\mathrm{N}$-doped carbon nanospheres have recently been investigated as nanozymes for catalytic cancer treatments by producing $\cdot \mathrm{OH}$ from $\mathrm{H}_{2} \mathrm{O}_{2}$ [20]. In this particular case, $\mathrm{N}$-doping was attributed to being responsible for the generation of hydroxyl radicals. N-doping has been previously revealed to cause charge redistribution around adjacent carbon atoms to induce the catalytic activities [21]. Similarly, defects in carbon nanomaterials could also alter charge distributions to induce catalytic performance [22, 23], which has been confirmed by recent experimental and theoretical studies for energy-related reactions (e.g., ORR) [21-24]. So far, however, there is no study on the mechanistic understanding of defectinduced biocatalytic behaviors.

Owing to their small size, unique physicochemical properties, and biocatalytic behaviors, graphene quantum dots (GQDs) have been investigated as promising C-MFC-based therapeutic agents [25]. Recent studies demonstrated that graphene quantum dots functionalized with and without targeting agent (s) can cause DNA damage via ROS generation to suppress the growth of cancer cells $[26,27]$. However, underlying mechanisms for the GQD-induced ROS generation have not yet been understood, though the associated ROS-induced DNA damage and biochemical anti-cancer effect have been widely studied. In this work, we have for the first time demonstrated the defect-induced ROS generation from GQD C-MFCs and hydrogen peroxide in TME and carried out the associated mechanistic study.

Herein, metal-free, doping-free, defect-rich GQDs were used to study the defect-induced catalytic generation of hydroxyl radicals $(\cdot \mathrm{OH})$ and the subsequent biological effects. Spin-trapped electron paramagnetic resonance (EPR) spectroscopy and colorimetric assay studies revealed that the catalytic performance strongly depends on the defect density. As schematically shown in Fig. 1, defect-rich GQDs could catalyze the efficient generation of hydroxyl radicals from hydrogen peroxide, especially in TME, to induce an efficacious anti-cancer effect even without the addition of any chemotherapeutic drugs. Our cellular and subcellular studies revealed multi-level anti-cancer mechanisms involving the cell membrane, mitochondria, and DNA damages by the defect-rich GQDs (Fig. 1). This newly observed GQD defect-induced catalytic ROS generation, along with the associated therapeutic effects in response to TME, represents the first proof of concept for the defect-induced metal-free catalytic therapeutic strategy towards safe and efficacious cancer treatment.

\section{Results and discussion}

\section{Synthesis and structural characterization of GQDs}

The GQDs used in this study were synthesized and purified via a typical electrochemical method without further modification, according to a published procedure [29]. GQDs-300 and GQDs-500 were obtained by annealing the purified GQDs at 300 and $500{ }^{\circ} \mathrm{C}$, respectively. The high-resolution transmission electron microscopic (HRTEM) examination revealed a spherical morphology with an average diameter of about $3.5 \mathrm{~nm}$ and crystal lattice spacing of $0.22 \mathrm{~nm}$ for the GQDs (Fig. 2a). The aqueous dispersion of GQDs was relatively stable at room temperature, which showed an average hydrodynamic particle size of $9.8 \mathrm{~nm}$ and zeta potential of $-28.5 \mathrm{mV}$ without obivious change over 30 days (Additional file 1: Figs. S1 and S2).

To investigate the chemical compositions of the GQDs, we performed X-ray photoelectron spectroscopy (XPS) and Fourier-transform infrared spectroscopy (FT-IR). XPS analyses indicate the presence of $\mathrm{C} \mathrm{(72} \mathrm{at \% )} \mathrm{and} \mathrm{O}$ (26 at\%) in GQDs (Fig. 2b). The corresponding ultraviolet-visible (UV-vis) absorption spectrum of the aqueous dispersion of GQDs shows a typical broad absorption peak at $230 \mathrm{~nm}$ attributable to $\pi=\pi^{*}$ transition of the aromatic $\mathrm{C}=\mathrm{O}$ bond [30] (Additional file 1: Fig.S4). Figure 2c shows photoluminescent emissions at different excitation wavelengths (from 350 to $800 \mathrm{~nm}$ ) for an aqueous dispersion of GQDs, indicating the highest emission peak at $450 \mathrm{~nm}$ under excitation at $340 \mathrm{~nm}$ (Fig. 2c). Figure $2 \mathrm{~d}$ reproduces the Raman spectrum for the GQDs, which shows the presence of the crystalline $G$ band $\left(1596 \mathrm{~cm}^{-1}\right)$ and disordered D band $\left(1331 \mathrm{~cm}^{-1}\right)$ with an $\mathrm{I}_{\mathrm{D}} / \mathrm{I}_{\mathrm{G}}$ ratio of 1.72, indicating a defect-rich structure [31].

For comparison, GQDs with relatively low defect densities were also synthesized via annealing under an argon 


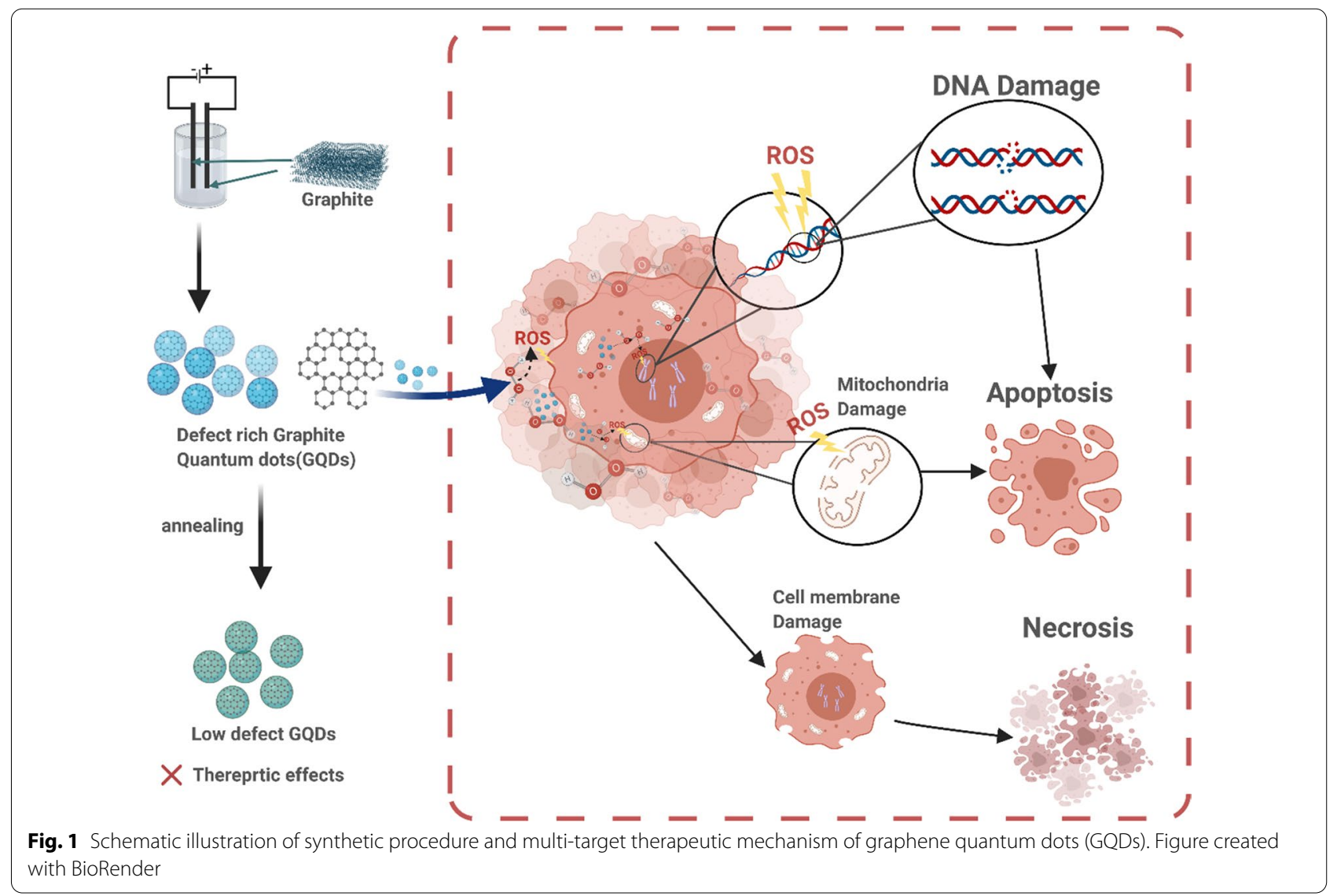

atmosphere at $300{ }^{\circ} \mathrm{C}$ (GQDs-300) and $500{ }^{\circ} \mathrm{C}$ (GQDs$500)$, as mentioned above. As expected, annealing at higher temperatures could effectively reduce the defect density, as demonstrated by the decreased $\mathrm{I}_{\mathrm{D}} / \mathrm{I}_{\mathrm{G}}$ ratios in the order of 1.72, 1.23 and 1.09 for the pristine GQDs, GQDs-300, and GQDs-500, respectively (Fig. 2d).

Figure $2 \mathrm{f}$ shows the band structure diagram for the GQDs, which was obtained from the corresponding optical energy gap, deduced from the longest absorption edge $\left(\lambda_{\text {onset }}, \mathrm{E}_{\mathrm{g}}^{\mathrm{opt}}=1.77 \mathrm{eV}\right)$ [32], and the highest occupied molecular orbital (HOMO) at the valence band from UPS (6.25 eV, Fig. 2e). The lowest unoccupied molecular orbital (LUMO) at the conduction band was then calculated to be: $\mathrm{E}_{\mathrm{g}}^{\mathrm{opt}}-\mathrm{HOMO}=1.77-6.25=-4.47$ (Fig. 2f, Additional file 1: Table S1). Based on the calculated band structure and redox potentials shown in Fig. 2f, the GQDs-defect catalyzed hydroxyl radical generation from $\mathrm{H}_{2} \mathrm{O}_{2}$ is plausible.

\section{Defect-induced catalytic activity}

We found that defect-rich GQDs possess a peroxidaselike activity that decomposes $\mathrm{H}_{2} \mathrm{O}_{2}$ into $\cdot \mathrm{OH}$. To test the catalytic performance of the GQDs, we used the 3,3,5,5-tetramethylbenzidine (TMB) assay, which can be oxidized by $\cdot \mathrm{OH}$ from $\mathrm{H}_{2} \mathrm{O}_{2}$ decomposition to a blue product with absorbance at $652 \mathrm{~nm}$ [33]. As shown in Additional file 1: Figs. S6 and S7, GQDs significantly increased the reaction rates of $\mathrm{H}_{2} \mathrm{O}_{2}$ decomposition, followed by $\cdot \mathrm{OH}$ induced TMB oxidation. By plotting initial velocities against $\mathrm{H}_{2} \mathrm{O}_{2}$ concentrations, we performed the kinetic analysis and calculated the Michaelis-Menten constant $(\mathrm{Km})$ and maximum initial velocity (Vmax) [20] to be $0.86 \mathrm{mM}$ and $5.4 \times 10^{-8} \mathrm{M} / \mathrm{s}$, respectively (Fig. 3a and Additional file 1: Figs. S5 and S7), indicating the high catalytic activity of GQDs [10]. We further used TMB and GQDs of different defect densities to investigate the effect of the defect density on the catalytic activity. As shown in Fig. 3b, the reaction velocity decreased dramatically from $100 \%$ for GQDs to $39 \%$ for GQDs-300 and 26\% for GQDs-500, indicating that a high defect density is critical to the enhanced catalytic activity. Experimental results revealed that the defective structure of GQDs induced the formation of positively and negatively charged carbon atoms to strengthen the chemisorption of hydrogen peroxide, leading to the reaction activation. This is because the defect structure breaks the perfect hexagon ring of graphitic carbon quantum dots, 


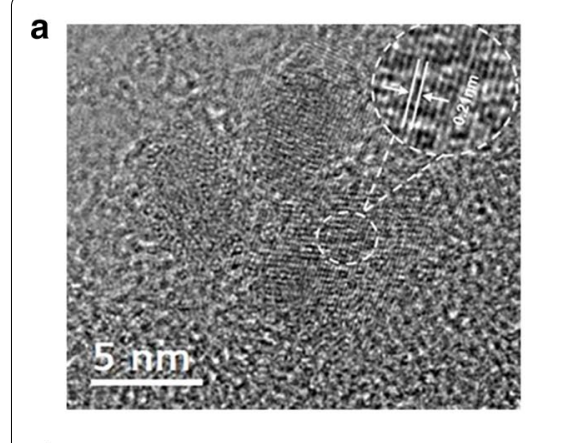

d

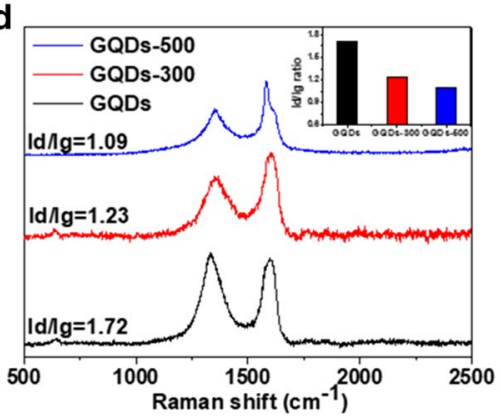

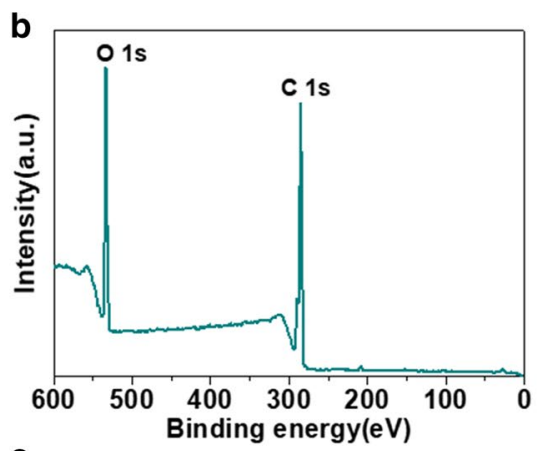

e

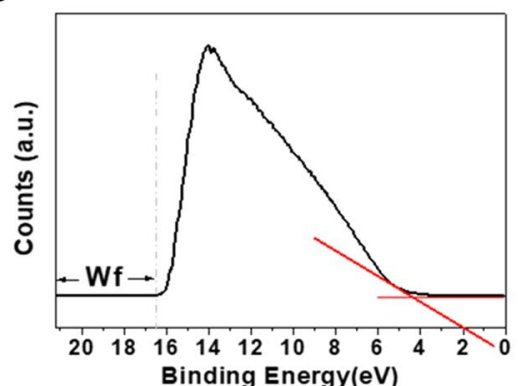

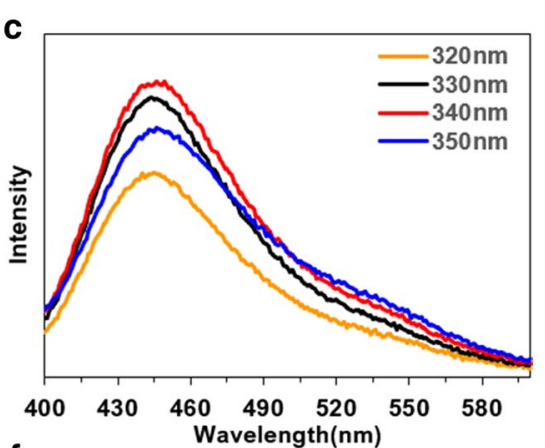

f

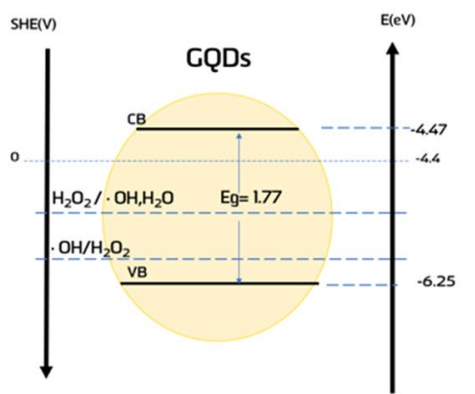

Fig. 2 Physicochemical properties of GQDs. a TEM image (scale bar $=5 \mathrm{~nm}$ ). b XPS survey spectra (insert: HR-XPS spectra of C1s). c Fluorescence emission spectrum at the excitation wavelength of different wavelengths ranging from 320 to $350 \mathrm{~nm}$. d Raman spectra of GQDs with different defect densities (insert: Id/Ig ratio of GQDs with different defect densities). e UPS spectra of GQDs. f Band structure of GQDs. Conduction band $(\mathrm{CV})=$ Valence band $(\mathrm{VB})+\mathrm{E}_{\mathrm{g}}^{\mathrm{opt}}[28]$

generating the unsymmetrical structure and altering the electron distribution of carbon skeleton [21,34,35].

To gain a mechanistic understanding of catalytic ROS generation, we used terephthalic acid (TA) as a specific hydroxyl radical probe to capture hydroxyl radicals for the generation of 2-hydroxyl terephthalic acid (TAOH) with fluorescence emission at $400 \mathrm{~nm}[36,37]$. The fluorescent intensity from a mixed solution of GQDs, $\mathrm{H}_{2} \mathrm{O}_{2}$ and TA significantly increased in comparison to the control solutions of TA, $\mathrm{H}_{2} \mathrm{O}_{2}+\mathrm{TA}$, and GQDs + TA, signifying the generation of abundant $\cdot \mathrm{OH}$ radicals from the interaction between GQDs and $\mathrm{H}_{2} \mathrm{O}_{2}$ (Fig. $3 \mathrm{c}$ and Additional file 1: Figs S8 and S9). This result suggests that GQDs possess the catalytic ability toward $\mathrm{H}_{2} \mathrm{O}_{2}$ decomposition to generate $\cdot \mathrm{OH}$. The catalytic nature of GQDs was further supported by the same chemical structure before and after the reaction, demonstrated by FT-IR spectra of GQDs (Additional file 1: Fig. S3).

\section{In vitro ROS regulation and the associated biological effects in TME}

As can be seen from the above discussion, the defect-rich GQDs can induce peroxidase-like catalytic reactions to decompose $\mathrm{H}_{2} \mathrm{O}_{2}$ into $\cdot \mathrm{OH}$. To further confirm this, we firstly used electron paramagnetic resonance (EPR) spectroscopy, in conjunction with 5,5-dimethyl-1-pyrroline
$\mathrm{N}$-oxide (DMPO) as a typical nitrone spin trap, to identify $\cdot \mathrm{OH}$ species [38]. As shown in Fig. 3d, EPR spectra reveal a characteristic 1:2:2:1 signal pattern of $\cdot \mathrm{OH}$ in the sample containing both $\mathrm{H}_{2} \mathrm{O}_{2}$ and GQDs, but not in the samples without GQDs or $\mathrm{H}_{2} \mathrm{O}_{2}$. These results confirm that the GQDs can catalyze $\mathrm{H}_{2} \mathrm{O}_{2}$ decomposition to generate $\cdot \mathrm{OH}$ (Fig. 3d and Additional file 1: Fig.S10). To study the effect of hydroxyl radicals on cultured cancer cells, we incubated $1 \times 10^{6} / \mathrm{ml}$ human breast cancer MCF-7 cells in a mixture of $\mathrm{H}_{2} \mathrm{O}_{2}$ and GQDs $(50 \mu \mathrm{g} / \mathrm{ml})$ for $60 \mathrm{~min}$. Aliquots collected from the fresh mixture and after $10 \mathrm{~min}$ or $60 \mathrm{~min}$ were evaluated by EPR using the DMPO nitrone spin trap. As shown in Fig. 3e, f, MCF-7 cancer cells continuously consumed $\cdot \mathrm{OH}$ generated from the GQDs catalyzed $\mathrm{H}_{2} \mathrm{O}_{2}$ decomposition.

To investigate the subcellular accumulation of GQDs, we performed the intracellular mapping of GQDs in MCF-7 cell culture by using dyes Dil and NucRed647 for visualizing plasma membrane and nuclei, respectively. As shown in confocal microscopy images given in Fig. 4a, b (Additional file 4: Movie S3 and Additional file 5: Movie S4), the GQDs with blue fluorescence emission under 405-nm excitation were found in both cytoplasm and nuclei in an aggregated form, and this finding is also further supported by TEM images in Additional file 1: Fig. S15. The driving force for GQDs to penetrate the cells 

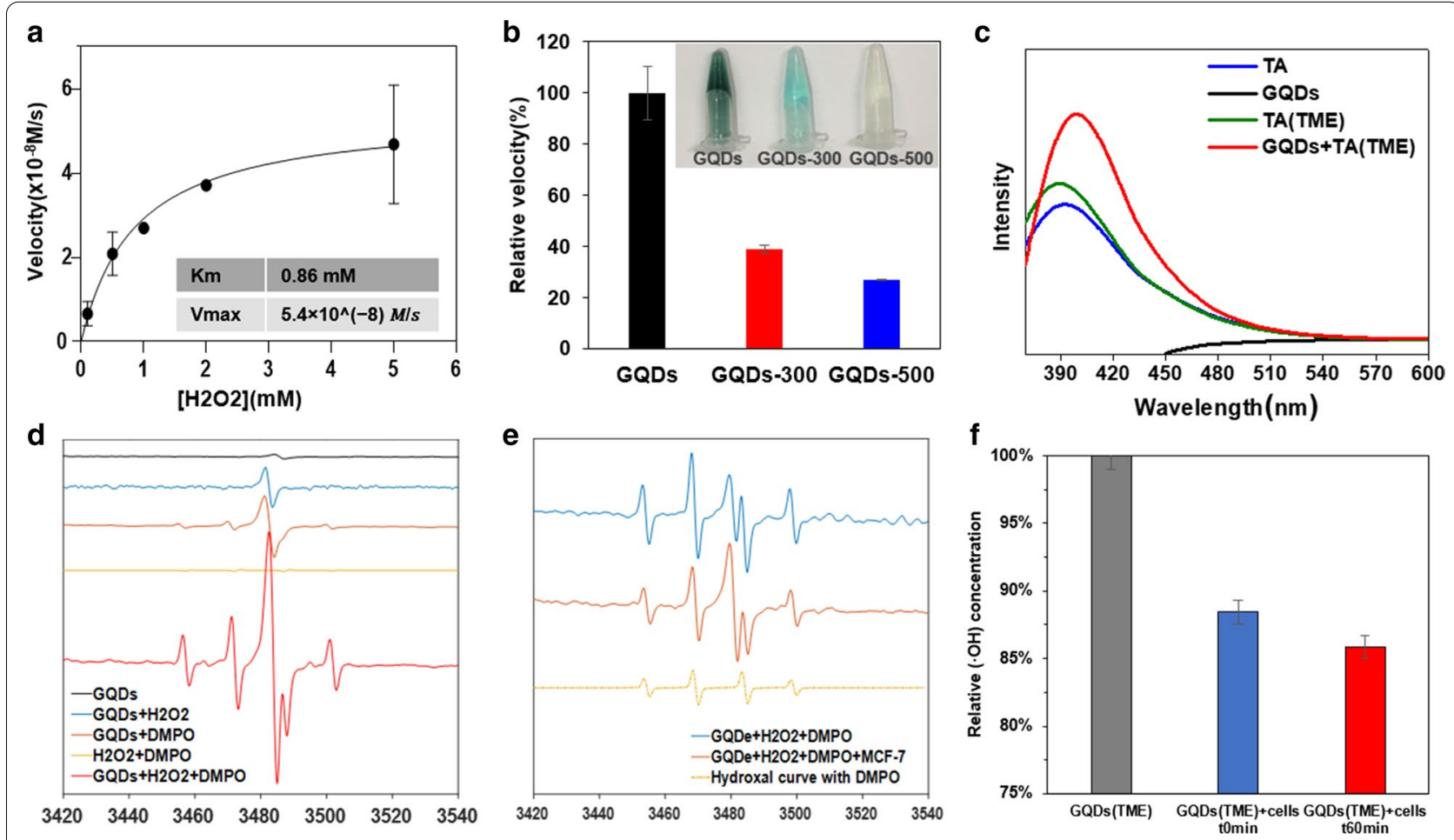

Fig. 3 Catalytic performance of GQDs. a Michaelis-Menten kinetic profile. $\mathbf{b}$ Catalytic performance comparison via relative reaction velocity from

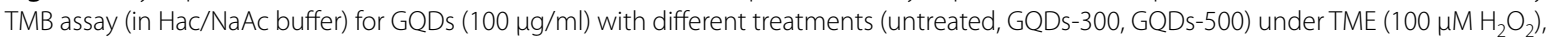
insert: photo of TMB colorimetric assay at 10 min post-treatment of GQDs, GQDs-300, GQDs-500. c Fluorescence spectra of TA, GQDs, TA (TME) and GQDs + TA (TME) in PBS. The concentration of TA, TME $\left(\mathrm{H}_{2} \mathrm{O}_{2}\right)$ and GQDs in PBS were $1 \mathrm{mM}, 100 \mu \mathrm{M}$ and $100 \mu \mathrm{g} / \mathrm{ml}$, respectively. Hydroxyl radical identification via EPR using DMPO (1 mM) as the spin trap of: $\mathbf{d}$ GQDs $(50 \mu \mathrm{g} / \mathrm{ml})$ with and without $\mathrm{H}_{2} \mathrm{O}_{2}(1 \mathrm{mM})$, and e $\mathrm{GQDs}_{+}+\mathrm{H}_{2} \mathrm{O}_{2}$ with and without adding MCF-7 cells $\left(1 \times 10^{6} / \mathrm{ml}\right)$. f Relative hydroxyl radical concentrations calculated from the signals in using Xenon quantify EPR software

and accumulate in nuclei is probably arising from both the size effect and the $\pi-\pi$ stacking interactions between GQDs and DNA chains [26].

Hydrogen peroxide overexpression is a well-known hallmark of cancers, which can show a tenfold increase compared to normal cells [7]. Thus, the above-demonstrated catalytic capability of GQDs can be exploited to decompose $\mathrm{H}_{2} \mathrm{O}_{2}$ into cytotoxic $\cdot \mathrm{OH}$ radicals to efficiently kill cancer cells, particularly in the tumor microenvironment. In this study, we used DCFH-DA as a fluorescence probe to evaluate the intracellular radical generation in response to GQDs in the tumor microenvironment. It is known that DCFH-DA can permeate into cells and be intracellularly hydrolyzed to DCFH, then further oxidized by intracellular ROS to fluorescent product dichlorofluorescein (DCF) [39]. The time-dependent, TME-responsive, GQDs-induced ROS generation was demonstrated by DCF fluorescence intensities recorded on a photoluminescent spectrometer at 2, 15, and $24 \mathrm{~h}$ after the addition of GQDs. Figure $4 \mathrm{c}$ shows a burst production of ROS within the first 2-h treatment of GQDs in the tumor microenvironment, followed by a continued increase in the intracellular ROS level over $24 \mathrm{~h}$.
In contrast, a retarded low-level ROS generation was observed in control experiments without GQDs or TME (Fig. 4c). The intracellular ROS levels were also visualized by confocal microscopy (Fig. 4d). As expected, significant fluorescence emissions from DCF were observed in the treatment group of GQDs in TME, rather than in the control groups (i.e. PBS, TME, GQDs). The intracellular level of ROS was further quantified via flow cytometry, which demonstrated $0.81 \%, 16 \%$ and $44.4 \%$ of fluorescent cells for the GQDs, TME, and GQDs (TME), respectively (Fig. 4e), confirming, once again, that the defectrich GQDs can catalyze the generation of a considerable amount of ROS in the tumor microenvironment.

To evaluate the biologic effects of GQDs-mediated catalytic ROS generation, we measured the cell viability of breast cancer cells (4T1, MDA-MB-231, MCF-7) via CCK- 8 assay by incubating three types of cell lines with GQDs at various concentrations under the TME-mimic conditions $\left(100 \mu \mathrm{M} \mathrm{H}_{2} \mathrm{O}_{2}\right)$ [40]. It is interesting to note that the addition of low-concentration hydrogen peroxide $(\leq 100 \mu \mathrm{M})$ caused a slight increase in the cell viability of 4T1 (Additional file 1: Fig. S11), attributable to the fact that hydrogen peroxide could activate cancer 


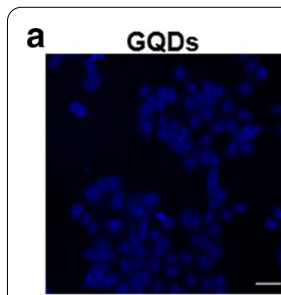

b

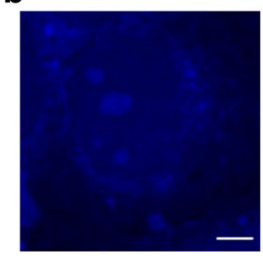

d
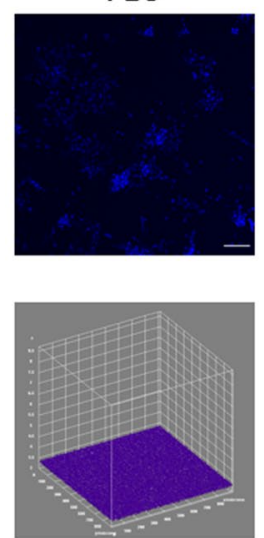

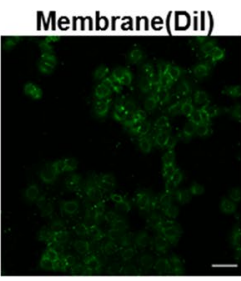

Membrane(Dil)

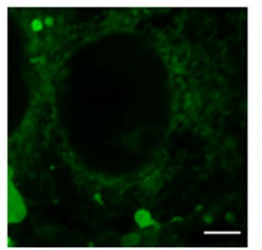

TME
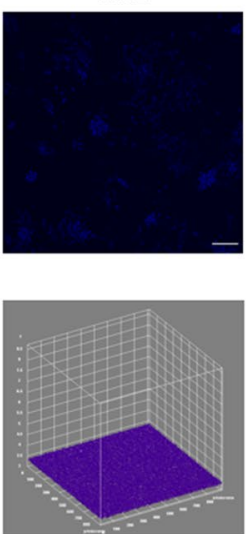

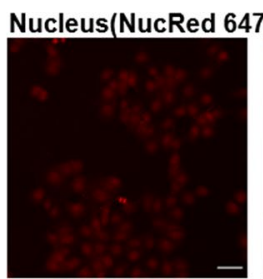

Nucleus(NucRed 647)

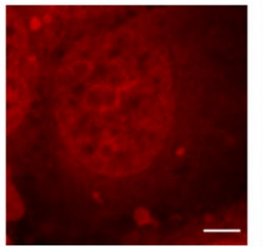

GQDs
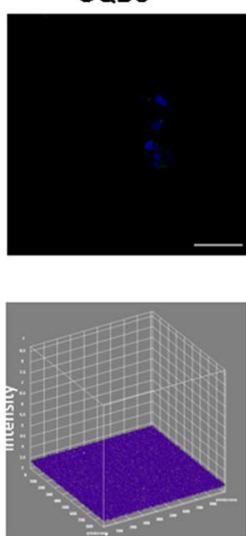

merged

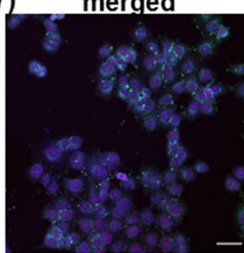

merged
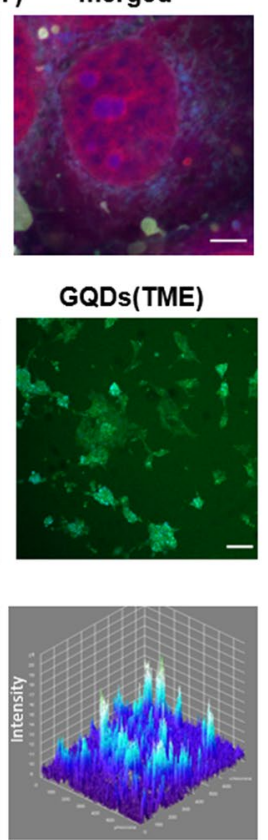

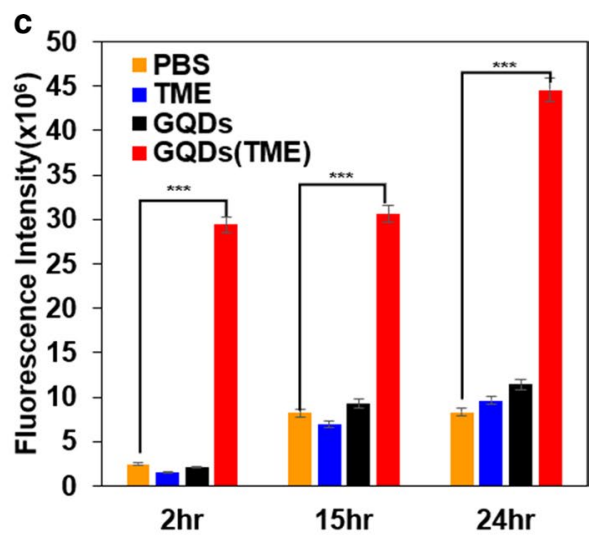

e

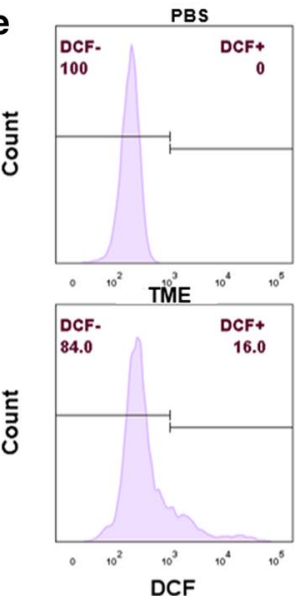

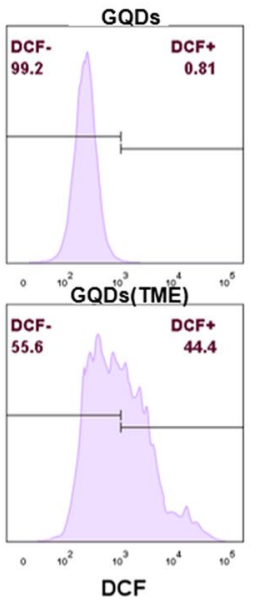

Fig. 4 Cellular localization of GQDs and intracellular ROS generation. a, b Confocal microscopy images of GQDs-treated MCF-7 cells (a: scale bar:

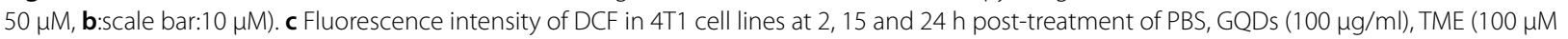
$\left.\mathrm{H}_{2} \mathrm{O}_{2}\right)$, GQD (TME) $\left(100 \mu \mathrm{g} / \mathrm{ml} \mathrm{GQDs}+100 \mu \mathrm{M} \mathrm{H}_{2} \mathrm{O}_{2}\right)$. d intracellular ROS level in 4T1 cells (green signals from DCF indicate ROS; blue signals from DAPI indicate nuclei), scale bar: $100 \mu \mathrm{m}$. e Quantified intracellular ROS level in 4T1 cells treated with agents: PBS, GQDs (100 $\mu \mathrm{g} / \mathrm{ml}), \mathrm{TME}(100 \mu \mathrm{M}$ $\left.\mathrm{H}_{2} \mathrm{O}_{2}\right)$, GQD (TME) $\left(100 \mu \mathrm{g} / \mathrm{ml} \mathrm{GQDs}+100 \mu \mathrm{M} \mathrm{H}_{2} \mathrm{O}_{2}\right)$ for $2 \mathrm{~h}$, measured by flow cytometry. Data are presented as mean \pm standard deviation, and analyzed by unpaired Student's two-tailed t-test, compared to PBS group. ${ }^{*} p<0.05,{ }^{* *} p<0.01,{ }^{* * *} p<0.001$

cell growth by promoting cell malignant transformation and expression of $\mathrm{H}_{2} \mathrm{O}_{2}$-detoxifying compounds [7]. As shown in Fig. 5a, a GQDs concentration-specific and TME-selective cell viability was observed under TME conditions. Specifically, in 4T1 cell cultures, GQDs under TME achieved $80 \%$ inhibition on cell viability at $200 \mu \mathrm{g} / \mathrm{ml}$ GQDs, with a half maximum inhibitory concentration (IC50) of $50 \mu \mathrm{g} / \mathrm{ml}$ (Fig. 5a). When the GQD concentration increased from 1 to $200 \mu \mathrm{g} / \mathrm{ml}$, cell viability decreased from $70 \%$ to $20 \%$. Similarly, defectrich GQDs exhibited dosage-dependent cytotoxicity on MDA-MB-231 and MCF-7 cells under the TME conditions. In contrast, there was no obvious change in cell viability for the control groups (i.e., PBS, TME, GQDs), and normal fibrolast cell NIH-3T3 can tolerate GQDs at the concentrations up to $250 \mu \mathrm{g} / \mathrm{ml}$ (Additional file 1 : Fig. S12). The TME-responsive therapeutic effects of GQDs were further visualized by staining cells with propidium iodide (PI that stains dead cells) via timelapse live-cell fluorescence imaging (Additional file 2: Movie S1 and Additional file 3: Movie S2). After the treatment with $100 \mu \mathrm{g} / \mathrm{ml}$ GQDs and $100 \mu \mathrm{M} \mathrm{H}_{2} \mathrm{O}_{2}$, the number of 4T1 cells did not increase while the cancer cells in control group (PBS) grew remarkably over $24 \mathrm{~h}$. Meanwhile, the red fluorescence signals of non-viable cells (PI dye) significantly increased during the 24-h treatment period, in comparison to the control groups. These results indicate that GQDs can efficiently interact with cancer cells and suppressed cell growth in the $\mathrm{H}_{2} \mathrm{O}_{2}$-rich tumor microenvironment. Moreover, the 

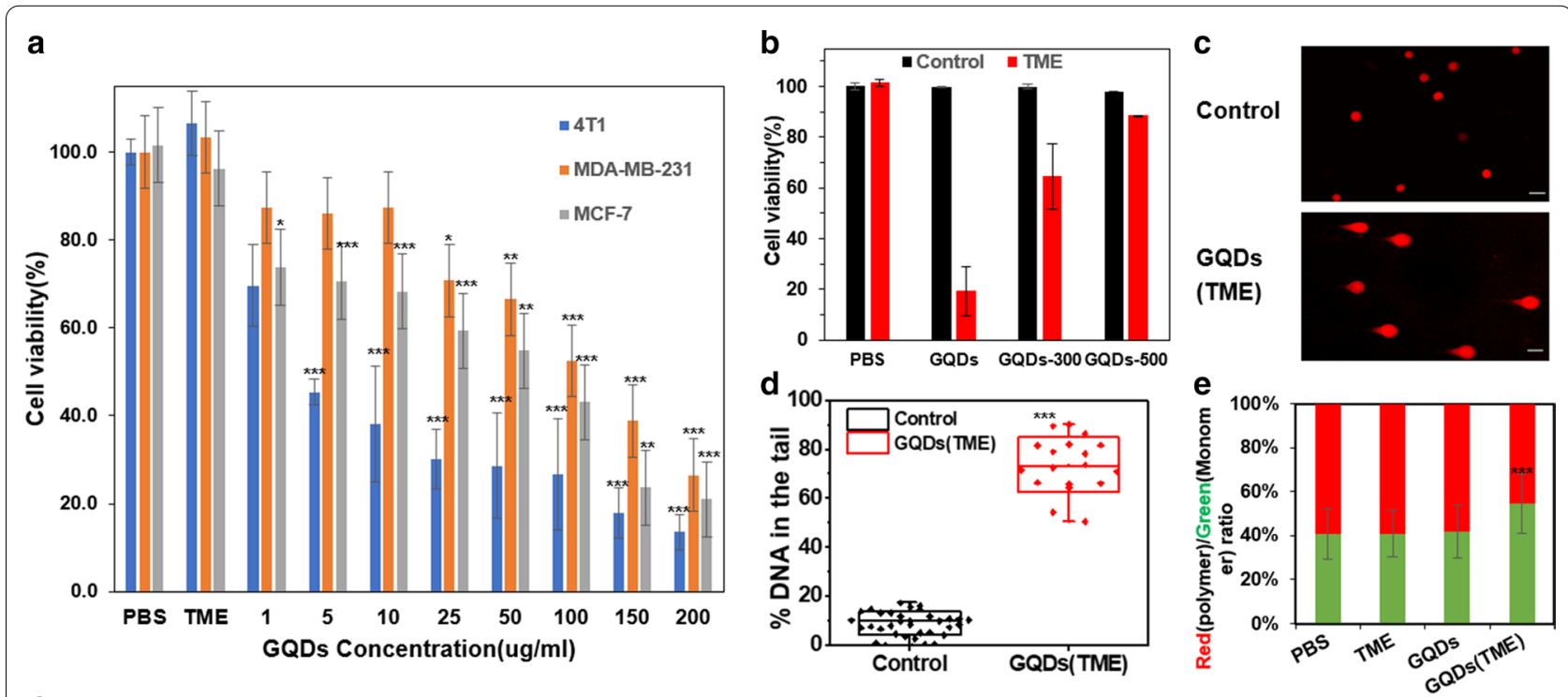

f
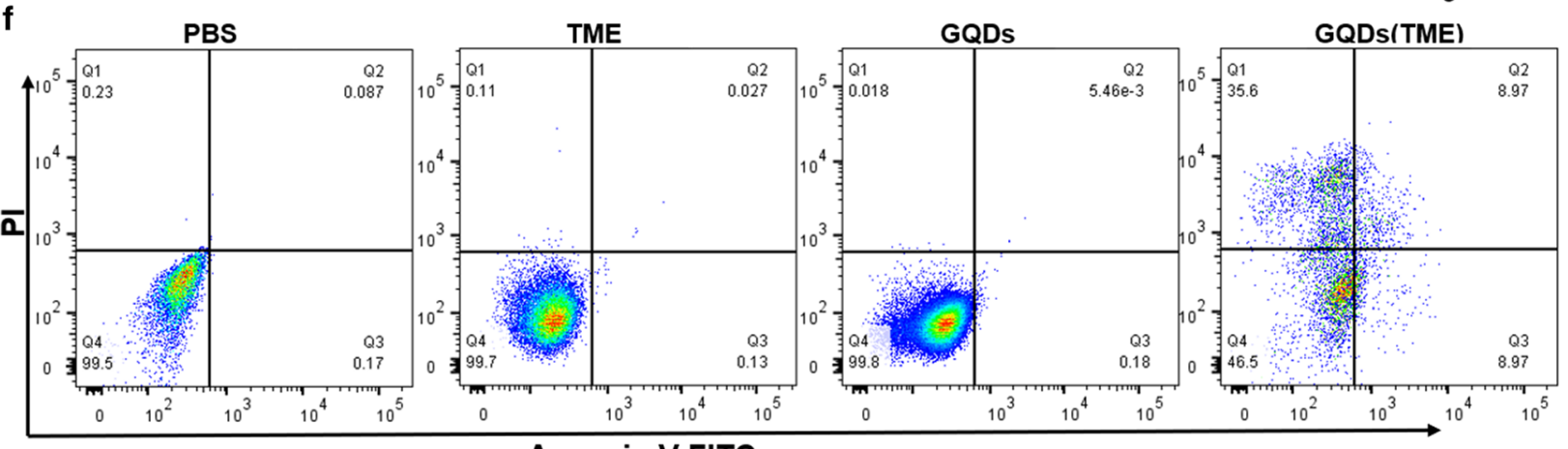

Annexin V-FITC

Fig. 5 Therapeutic effects of GQD under TME. a Cell viability of 4T1/MDA-MB-231/MCF-7 cells treated with PBS, $100 \mu M \mathrm{H}_{2} \mathrm{O}_{2}$ (TME), or GQDs $(1-200 \mu \mathrm{g} / \mathrm{ml})+100 \mu \mathrm{M} \mathrm{H}_{2} \mathrm{O}_{2}$ under TME, for $24 \mathrm{~h}$. b Cell viability of 4T1 cells treated with PBS, GQDs, GQDs-300 or GQDs-500 for $24 \mathrm{~h}$. c Neutral comet assay of GQDs $(200 \mu \mathrm{g} / \mathrm{ml})$ under TME, scale bar: $200 \mu \mathrm{m}$. d Quantitative analysis of alkaline comet assay based on 30 cell samples. e The ratio of red (JC-1 polymer) over green (JC-1 monomer) fluorescence intensity of different treatment groups including PBS, TME, 100 Mg/ml GQDs, and GQDs $(1-100 \mu \mathrm{g} / \mathrm{ml})+100 \mu \mathrm{M} \mathrm{H}_{2} \mathrm{O}_{2}$, representing the changes in mitochondria membrane potential. f Apoptosis analysis via flow cytometry. Data are presented as mean \pm SD. Statistical significance was analyzed by unpaired Student's two-tailed t-test compared to the PBS group. ${ }^{*} p<0.05$, ${ }^{* *} p<0.01,{ }^{* * *} p<0.001$

anti-cancer efficiency of GQDs increased with increasing in the defect density of GQDs (Fig. 5b), consisting well with their defect-density-dependent catalytic activities (vide supra).

As a consequence, excessive ROS damages lipids, proteins, and DNA, leading to cell death [41]. To further investigate the anti-cancer mechanism of ROS generated from the GQDs-catalyzed $\mathrm{H}_{2} \mathrm{O}_{2}$ decomposition, we conducted comet assays to assess DNA damage. The round nuclear DNA without tails observed in the control groups indicates no obvious DNA damage, while the cells treated with GQDs under TME exhibited comet tails characteristic of DNA damage (Fig. 5c, d and Additional file 1: Fig.
S14). Double-strand DNA breaks were revealed by a neutral comet assay (Fig. 5c). An average of $73 \%$ overall DNA damage was observed by alkaline comet assay (Fig. $5 \mathrm{~d}$ ). Therefore, the observed cell death could be attributed to the DNA damage-induced apoptosis caused by GQDscatalyzed ROS generation. Mitochondria damage was also observed by measuring the mitochondrial membrane potential using lipophilic cationic dye JC-1 [42]. Specifically, JC-1 staining illustrated that mitochondrial potential was reduced after the GQDs treatment under TME (Fig. 5e), indicating significant mitochondria damage, which could also trigger the intrinsic apoptosis pathway $[2,43]$. However, it cannot be ruled out that necrosis 
could also be triggered by the plasma membrane, a double layer of lipid and proteins, damage by the robust ROS level.

\section{Cell death pathway}

To investigate the cell death pathways, we employed annexin V-FITC/PI and flow cytometry to examine the effect of GQDs on cell necrosis and apoptosis. FITC conjugated Annexin $\mathrm{V}$ is typically used to detect apoptosis via binding to phosphatidylserine (PS), which is an apoptosis marker that transports from the inner to the outer leaflet of the plasma membrane upon receiving proapoptotic signals $[44,45]$. PI acts as an impermeant cell dye that binds to DNA and stains cells with the broken cell membrane to indicate necrosis or late-stage apoptosis $[45,46]$. As shown in Fig. 5f, GQDs therapeutic treatment in TME elicited remarkable necrosis $(25.6 \%$, Q1, PI+/Annexin V-) and significant apoptosis (17.8\%, $\mathrm{Q} 2+\mathrm{Q} 4$, the sum of PI-/Annexin V+and PI+/Annexin $\mathrm{V}+$ ) in $4 \mathrm{~T} 1$ cells, compared to the controls (i.e. GQDs, TME) that showed neglectable necrosis and apoptosis. Notably, necrotic cell death is closely associated with cell membrane rupture that is likely caused by the peroxidase-like activity of GQDs and -OH-induced lipid peroxidation. Apoptosis could be ascribed to mitochondria damage and/or DNA damage, which is consistent with the ROS cancer inhibition mechanism discussed above.

In summary, we have demonstrated the ROS generation from $\mathrm{H}_{2} \mathrm{O}_{2}$ decomposition catalyzed by defect-rich metal-free GQDs and elucidated the associated anticancer mechanism. Defect-induced, GQDs-concentrationdependent, tumor microenvironment-selective cancer cell apoptosis was observed. Specifically, defect-rich GQDs exhibited high catalytic activities for the generation of abundant hydroxyl radicals from $\mathrm{H}_{2} \mathrm{O}_{2}$ decomposition in the tumor microenvironment, showing remarkable inhibition effects toward cancer cells through multiple cellular component failures. The produced hydroxyl radicals caused DNA damage, interfered with mitochondria, and triggered subsequent apoptotic cell death pathways, while they could also damage cell membrane, leading to cell necrosis. The demonstrated proof-of-concept and mechanistic understanding of the ROS generation from $\mathrm{H}_{2} \mathrm{O}_{2}$ decomposition catalyzed by defect-rich GQDs in the tumor microenvironment for cancer cell apoptosis/ necrosis via DNA damage/cell membrane damage provide a promising strategy for the design and development of carbon catalyst-based safe and efficacious cancer therapy. Owing to their facile synthesis, high selectivity to the tumor microenvironment, and highly efficient therapeutic ROS generation, we envision that the defect-rich GQDs hold great potential for high-performance nanomedicine in future preclinical and clinical trials.

\section{Methods \\ Materials}

Graphite rod (>99.99999\%), terephthalic acid (TA),5,5dimethyl-1-pyrroline-N-oxide (DMPO), 3,5,5-tetramethylbenzidine (TMB), hydrogen peroxide, cell count kit-8 (CCK-8), were purchased from Sigma. Dulbecco's Modified Eagle Medium (DMEM, \#11995073), Gibco Roswell Park Memorial Institute- 1640 (RMPI 1640, \#22400105) medium were purchased from Thermofisher. Mili-Q water was used for synthesis and purification. Cell lines 4T1 (ATCCRL2541) and NIH 3 T3 (\#93061524) were obtained from American Type Culture Collection (ATCC) and CellBank Australia, respectively; $M C F-7$ and $M D A-M B-231$ cells were obtained from Sigma.

\section{Synthesis of GQDs}

GQDs were synthesized according to the published electrochemical method [29]. Briefly, two graphite rods (>99.99999\%, Sigma) as anode and cathode were inserted in ultrapure MiliQ water and subjected to $30 \mathrm{~V}$ from a direct current power supply. After the electrochemical reaction for $120 \mathrm{~h}$, a dark brown solution was obtained, from which GQDs were collected and purified via centrifugation at $10000 \mathrm{rpm}$ for $1 \mathrm{~h}$, followed by filtration and freeze-drying.

\section{Synthesis of GQDs-300 and GQDs-500}

To produce GQDs-300 and GQDs-500, GQDs were treated at $300{ }^{\circ} \mathrm{C}$ and $500{ }^{\circ} \mathrm{C}$, respectively, for $30 \mathrm{~min}$ in the tube furnace with a ramp rate of $5{ }^{\circ} \mathrm{C} / \mathrm{min}$ under argon atmosphere.

\section{Characterization of GQDs}

HRTEM images were recorded on a JEOL-F200 scanning transmission electron microscope (S/TEM) equipped with a cold field emission gun and an EDS detector at an acceleration voltage of $200 \mathrm{kV}$. Raman spectra were recorded on a Rennishaw InVia 2 Raman Microscope (532 $\mathrm{nm}$ excitation, 1\% laser power). X-ray photoelectron spectroscopy (XPS) was performed on a Thermo scientific ESCALAB250Xi spectrometer using a monochromatic $\mathrm{Al} \mathrm{K}$ alpha X-ray source (energy $1486.68 \mathrm{eV}$ ) operated at $120 \mathrm{~W}(13.8 \mathrm{kV} \times 8.7 \mathrm{~mA})$. Fourier-transform infrared spectroscopy was measured by Bruker compact FT-IR spectrometer ALPHA. Fluorescent emission spectroscopy was recorded on SHIMADZU RF-5301PC Spectrofluorophotometer. Ultraviolet photoelectron spectroscopy (UPS) data were obtained using the same instrument as XPS with a helium I ultraviolet source (energy $21.2 \mathrm{eV}$ ). The hydrodynamic size distribution (DLS) and zeta potential were measured on Zetasizer Nanoseries (Malvern). 


\section{Catalytic performance evaluation}

Michaelis-Menten kinetics. 3,3,5,5'-Tetramethylbezine (TMB) was introduced to exam the catalytic performance and study the kinetic profiles, as the TMB undergoes a color oxidation reaction from colorless to blue to show absorption at $652 \mathrm{~nm}$, which was measured by UV-vis (JASCO V-770). The TMB concentration was calculated from absorbance via the Beer-Lambert law [47]:

$$
A=\varepsilon b c
$$

where $A$ is the absorbance, $\varepsilon$ is the molar absorption coefficient of the oxidized TMB [48] $\left(39,000 \mathrm{M}^{-1} \mathrm{~cm}^{-1}\right), b$ is the optical length $(1 \mathrm{~cm})$, and $c$ is the concentration of the oxidized TMB. Therefore, $c$ was calculated by:

$$
d c=\frac{d A}{\varepsilon b}=\frac{d A}{39000 \times 1}(M)
$$

The following condition was applied for relative activity test: TMB concentration: $800 \mu \mathrm{g} / \mathrm{ml}$, Sample: 50 $\mu \mathrm{L}, \mathrm{H}_{2} \mathrm{O}_{2}$ concentration: $1 \mathrm{mM}$, at room temperature. Michaelis-Menten equation was selected as the model to analyze the enzyme kinetic [49].

$$
V_{0}=V_{\max } \frac{[S]}{[S] \times K_{m}}
$$

The Michaelis-Menton constant $(\mathrm{Km})$ and the maximum velocity $(\mathrm{Vm})$ were achieved with the use of curve-fitting programs GraphPad Prism 9 software (the Michaelis- Menton curve fitting) [33, 48].

\section{Free radical identification}

EPR signal was recorded on Bruker EMX X-Band EPR Spectrometer. In a typical experiment, DMPO $(5 \mathrm{mM})$ [50] was added into the PBS buffer solution containing $50 \mu \mathrm{g} / \mathrm{ml}$ GQDs, to which $1 \mathrm{mM}$ of $\mathrm{H}_{2} \mathrm{O}_{2}$ was added right before the measurements. The quantified analysis was performed using Xenon quantify EPR for peaks from 3450-3505 with the $2^{\text {nd }}$ baseline correction [51]. Radical concentrations were derived from the standard radical concentration curves, which were created based on the measurements of the ammonium iron sulfate $\mathrm{Fe}\left(\mathrm{NH}_{4}\right)_{2}\left(\mathrm{SO}_{4}\right)_{2} \cdot 6 \mathrm{H}_{2} \mathrm{O}$ and hydrogen peroxide $[51,52]$.

\section{Cell culture}

Breast cancer cell lines 4T1, MCF-7, MDA-MB-231, and fibroblast cell line NIH-3T3 were cultured in complete growth media (CGM) at $37^{\circ} \mathrm{C}$ with $5 \% \mathrm{CO}_{2}$. CGM for MCF-7, MDA-MB-231, and NIH-3T3 cell lines are DMEM containing $10 \%$ fetal bovine serum (FBS) and $1 \%$ penicillin-streptomycin, i.e., penicillin $100 \mathrm{units} / \mathrm{ml}$ and streptomycin $100 \mu \mathrm{g} / \mathrm{ml}$. CGM for the $4 \mathrm{~T} 1$ cell line is RMPI-1640 containing 10\% fetal bovine serum (FBS), and $1 \%$ penicillin-streptomycin. The cells were cultured at $37{ }^{\circ} \mathrm{C}$ in a humidified atmosphere with $5 \% \mathrm{CO}_{2}$ and passaged when reaching ATCC recommended confluency.

\section{Cellular localization of GQDs}

The cellular uptake biodistribution of GQDs was visualized by confocal microscopy. Briefly, coverslips were pre-disinfected and placed in a 24-well plate, followed by seeding $500 \mu \mathrm{l}$ of MCF-7 cells in coverslip $\left(1 \times 10^{5}\right.$ cells/ $\mathrm{ml})$. At $50 \%$ confluency, the CGM was removed, and cells were treated with PBS (control), TME $\left(\mathrm{H}_{2} \mathrm{O}_{2} 100 \mu \mathrm{M}\right)$, and GQDs $(100 \mu \mathrm{g} / \mathrm{ml})$ only and GQDs (TME, $\mathrm{H}_{2} \mathrm{O}_{2}$ $100 \mu \mathrm{M})$ at $37^{\circ} \mathrm{C}$. After $24 \mathrm{~h}$, the medium was removed, followed by rinsing with PBS three times. Cells were then stained with cell labels according to the manufacturer's instructions. Five $\mu \mathrm{L}$ Dil cell membrane dye (Invitrogen ${ }^{\mathrm{TM}}$, V22885) and $995 \mu \mathrm{L}$ serum-free medium were added into each well, incubated for $10 \mathrm{~min}$ at $37{ }^{\circ} \mathrm{C}$. Dil membrane dye was then removed and cells were washed with PBS three times. Two drops of NucRed live 647 in $1 \mathrm{~mL}$ of fresh medium were added to each well. After $15 \mathrm{~min}$ incubation at $37{ }^{\circ} \mathrm{C}$, cells were fixed with $4 \%$ PFA and mounted with prolong diamond Antifade mountant and observed under the confocal microscope (Zeiss 780/900).

\section{Intracellular ROS detection}

Cell-permeable probe 2,7-Dichlorofluorescin diacetate $\left(\mathrm{H}_{2} \mathrm{DCFDA}\right)$ was used to analyze the intracellular ROS generation via plate reader, confocal microscopy and flow cytometry. Briefly, $500 \mu \mathrm{l}$ of $4 \mathrm{~T} 1$ cells were seeded in a 24 -well plate $\left(1 \times 10^{5}\right.$ cells $\left./ \mathrm{ml}\right)$. At $50 \%$ confluency, cells were washed with PBS three times and then incubated with DCFH-DA $(10 \mu \mathrm{M})$ in serum-free RPMI 1640 for $30 \mathrm{~min}$ at $37^{\circ} \mathrm{C}$ in the dark. Then the medium was removed, followed by rinsing with PBS three times. Cells were treated with PBS (control), TME $\left(\mathrm{H}_{2} \mathrm{O}_{2} 100 \mu \mathrm{M}\right)$ and GQDs $(100 \mu \mathrm{g} / \mathrm{ml})$ only and GQDs (TME, $\mathrm{H}_{2} \mathrm{O}_{2}$ $100 \mu \mathrm{M})$. At 2, 15, $24 \mathrm{~h}$ post-treatment, the DCF intensity was recorded on the plate reader (Molecular Device SpectraMax iD5).

To visualize the intracellular ROS level, $500 \mu \mathrm{l}$ of $4 \mathrm{~T} 1$ cells were seeded on the coverslip $\left(1 \times 10^{5}\right.$ cells $\left./ \mathrm{ml}\right)$. At $50 \%$ confluency, cells were washed with PBS three times then incubated with DCFH-DA $(10 \mu \mathrm{M})$ in serum-free RPMI 1640 for $30 \mathrm{~min}$ at $37{ }^{\circ} \mathrm{C}$ in the dark. Then the medium was removed, followed by rinsing with PBS three times. Cells were treated with PBS (control), TME $\left(\mathrm{H}_{2} \mathrm{O}_{2} 100 \mu \mathrm{M}\right)$ or GQDs $(100 \mu \mathrm{g} / \mathrm{ml})$ only, and GQDs (TME, $\mathrm{H}_{2} \mathrm{O}_{2} 100 \mu \mathrm{M}$ ) for 2-h incubation. Then, the cells 
were fixed with $4 \%$ PFA and mounted with Prolong diamond Antifade mountant for examination by confocal microscopy (Zeiss 780/900).

For flow cytometry analysis, $2 \mathrm{ml}$ of $4 \mathrm{~T} 1$ cells $\left(3 \times 10^{5}\right.$ cells $\left./ \mathrm{ml}\right)$ were seed into a 6 -well plate. By following the same treatment procedure in the previous two experiments, cells were detached and collected, then measured immediately by flow cytometry (BD LSRFortessa) $(\lambda$ excitation $=488 \mathrm{~nm}$ and $\lambda$ emission $=530 \mathrm{~nm}$ ). The time course intensity measurements were carried out on a plate reader Molecular Device SpectraMax iD5, and the same seeding and treatments were applied to $4 \mathrm{~T} 1$. After different periods, the plate was measured under excitation and emission at $488 \mathrm{~nm}$ and $530 \mathrm{~nm}$, respectively.

\section{Cell viability assay}

CCK-8 assay was conducted to determine the in vitro cytotoxicity of GQDs. MCF-7/4T1/MDA-MB-231/3T3 cells were pre-incubated in a 96-well plate with a density of 5000 cells/well and cultured with $100 \mu \mathrm{l} \mathrm{com-}$ plete growth medium for $24 \mathrm{~h}$. Different concentrations of GQDs $(0-1000 \mu \mathrm{g} / \mathrm{ml}) / \mathrm{H}_{2} \mathrm{O}_{2}$ (0 to $1000 \mu \mathrm{M} \mu$ ) were added and then incubated for $24 \mathrm{~h}$. After that, $10 \mu \mathrm{l}$ of CCk- 8 reagent was added to each well and incubated for $4 \mathrm{~h}$ at $37^{\circ} \mathrm{C}$. The absorbance at $450 \mathrm{~nm}$ was measured using Molecular Device SpectraMax iD5. Data were presented as mean \pm SD from three independent experiments.

\section{Apoptosis analysis}

Cell Apoptosis was examined by annexin V/PI assay using Annexin V-FTIC apoptosis detection Kit (BNS500FI/100,eBioscience). 4T1 cells were pre-incubated in a 6-well plate at a density of 5000 cells/well and cultured with $2 \mathrm{ml}$ of complete growth medium. At $50 \%$ confluency, cells were treated with PBS (control), TME $\left(\mathrm{H}_{2} \mathrm{O}_{2} 100 \mu \mathrm{M}\right)$, and GQDs $(100 \mu \mathrm{g} / \mathrm{ml})$ only, and GQDs (TME, $\mathrm{H}_{2} \mathrm{O}_{2} 100 \mu \mathrm{M}$ ). After $24 \mathrm{~h}$ incubation, cells were detached and collected using trypsin-EDTA (centrifugation at $190 \mathrm{~g}$ for $5 \mathrm{~min}$ ). Cells were washed with PBS twice and binding buffer once (centrifugation at $200 \mathrm{~g}$ for $3 \mathrm{~min}$ ), and then resuspended in binding buffer containing Annexin V-FTIC (5:200) and incubated for $10 \mathrm{~min}$ at room temperature. Cells were washed with binding buffer and stain with PI (10:200) in binding buffer. The flow cytometry (BD LSRFortessa) was used to measure the fluorescence of Annexin VFITC and PI. All flow cytometry data were analyzed using Flowjo v10.

\section{DNA damage Study}

\section{Comet assay}

4T1/MCF-7/MDA-MB-231 cells were seeded in 6-well plates $\left(1 \times 10^{5}\right.$ cells $\left./ \mathrm{ml}\right)$. At $50 \%$ confluency, complete growth media were replaced with the medium containing different treatment agents (i.e. PBS, TME $\left(\mathrm{H}_{2} \mathrm{O}_{2} 100 \mu \mathrm{M}\right)$ or GQDs $(100 \mu \mathrm{g} / \mathrm{ml})$ only, and GQDs (TME, $\left.\mathrm{H}_{2} \mathrm{O}_{2} 100 \mu \mathrm{M}\right)$. After 24-h treatment, cells were detached with trypsin and resuspended in ice-cold PBS $\left(1 \times 10^{5}\right.$ cells $\left./ \mathrm{ml}\right)$, followed by cell lysis at $4{ }^{\circ} \mathrm{C}$ in dark for $2 \mathrm{~h}$. Comet assay was then performed according to the protocol from the manufacturer. Briefly, $1 \%$ agarose gel was made by adding $1 \mathrm{~g}$ of agarose into $100 \mathrm{ml}$ MiliQ water using the microwave method, and the gel was placed in a $37^{\circ} \mathrm{C}$ water bath for at least $20 \mathrm{~min}$ to cool. $1 \times 10^{5} / \mathrm{ml}$ cell samples were mixed with agarose $\left(\right.$ at $37{ }^{\circ} \mathrm{C}$ ) at a ratio of 1:10 (v/v) and $50 \mu \mathrm{l}$ mixture was immediately pipetted onto Comet Slides. Slides were placed at $4{ }^{\circ} \mathrm{C}$ in the dark for $30 \mathrm{~min}$. The slides were immersed in lysis Solution for $60 \mathrm{~min}$. Excess buffer was drained from slides which were then immersed in electrophoresis buffer (TBE for Neutral Comet and AES for Alkaline Comet) for $20 \mathrm{~min}$. After that, the horizontal electrophoresis cell (Bio-Rad) was filled with electrophoresis buffers. Electrophoresis was conducted at $30 \mathrm{~V}$ for $30 \mathrm{~min}$ in dark. Slides were gently removed from the electrophoresis tray and rinsed twice with Milli Q water and $70 \%$ ethanol $[53,54]$. Slides were dried and stained with SYBR Safe according to the manufacturer's instructions $(1: 10,000)$. Then, the images were captured using confocal microscopy (Zeiss 780/900). The results from comet assays were analyzed quantitatively by using ImageJ software by collectively monitoring more than 30 cells. \% DNA in the tail was calculated using the following Eq. [53, 55]:

$$
\% \text { DNA in Tail }=\left(1-\frac{\text { Total head DNA intensity }}{\text { Total DNA intensity }}\right) \times 100 \%
$$

Neutral electrophoresis solution: TBE (obtained from UNSW store).

Alkaline electrophoresis solution (AES): $200 \mathrm{mM}$ $\mathrm{NaOH}$ and $1 \mathrm{mM}$ disodium EDTA $\mathrm{pH}>13$.

\section{Mitochondria damage study}

JC-1 $\left(5,5^{\prime}, 6,6^{\prime}\right.$ - tetrachloro-1,1'3,3' -tetraethylimidacarbocyanine iodide, Abcam) was applied to measure membrane potential change of mitochondria. 4T1 cells were cultured in a 96-well plate (Corning) at a density of 5000 cells/well. A $50 \%$ confluency, the complete growth media were replaced with media containing different treatments (control (PBS), TME, GQDs $(100 \mu \mathrm{g} /$ 
$\mathrm{ml}$ ), GQD (TME)) after $24 \mathrm{~h}$ incubation. Then, cells were washed with JC-1 dilution buffer containing $10 \%$ FBS and stained with JC-1 working solution $(100 \mu \mathrm{l}, 1 \mu \mathrm{M})$ in the dark for 15 min. Thereafter, cells were washed with JC-1 dilution buffer twice and then emissions were recorded using Molecular Device SpectraMax iD5 (red: excitation: $530 \mathrm{~nm}$, emission: $590 \mathrm{~nm}$; green: excitation: $475 \mathrm{~nm}$, emission: $530 \mathrm{~nm}$ ).

\section{Supplementary Information}

The online version contains supplementary material available at https://doi. org/10.1186/s12951-021-01053-6.

Additional file 1: Table S1. Band structure and reference equation (1) \& (2). Table S2. Comparison of Km and Vmax for different catalyst. Figure S1. Hydrodynamic size distribution via DLS for GQDs. Figure S2. Zeta potential for GQDs. Figure S3. FT-IR spectra for GQDs before and after reaction. Figure S4. UV-Vis spectrum GQDs (5 $\mu \mathrm{g} / \mathrm{ml})$. Figure S5. Relative catalytic activity of GQDs at different $\mathrm{pH}$ values (a) and different temperature (b). Figure S6. Normalized absorbance (at $652 \mathrm{~nm}$ ) of GQDs under TME mimic conditions (TMB $(800 \mu \mathrm{g} / \mathrm{ml})+$ GQDs $(100 \mu \mathrm{g} / \mathrm{ml})+$ $100 \mu \mathrm{M} \mathrm{H}_{2} \mathrm{O}_{2}$ ) and control groups (MiliQ Water (solvent), TMB $(800 \mu \mathrm{g} / \mathrm{ml})$, TMB $(800 \mu \mathrm{g} / \mathrm{ml})+\mathrm{GQDs}(100 \mu \mathrm{g} / \mathrm{ml})$, TMB $\left.(800 \mu \mathrm{g} / \mathrm{ml})+100 \mu \mathrm{M} \mathrm{H}_{2} \mathrm{O}_{2}\right)$. Figure S7. Time course TMB assay - absorbance (at $652 \mathrm{~nm}$ ) of GQDs (50 $\mu \mathrm{g} / \mathrm{ml})$ with different concentration of $\mathrm{H}_{2} \mathrm{O}_{2}(0.1,0.5,1,2 \mathrm{mM})$. Figure S8. Reaction between hydroxyl radical and terephthalic acid (TA). Figure S9. Terephthalic acid (TA) intensity over time via fluorescence spectrometry. Figure S10. ESR spectra of GQDs $(50 \mu \mathrm{g} / \mathrm{ml})+\mathrm{H}_{2} \mathrm{O}_{2}(1 \mathrm{mM})+\mathrm{DMPO}(5$ $\mathrm{mM}$ ) comparing with typical hydroxyl radicals pattern with DMPO. Figure S11. Tolerance of $4 \mathrm{~T} 1$ cell line with $\mathrm{H}_{2} \mathrm{O}_{2}\left(0_{-1} \mathrm{mM}\right)$ after $24 \mathrm{~h}$. Figure S12. Biosafety of GQDs. Cell viability of normal cell NIH-3T3 cells treated with different concentration of GQDs $(0-1000 \mu \mathrm{g} / \mathrm{ml})$ for $24 \mathrm{hr}$. Figure S13. Living cell imaging results: percentage of confluence for 4T1/MCF-7 cell lines under GQDs (CQDs $100 \mu \mathrm{g} / \mathrm{ml})$ in TME $\left(\mathrm{H}_{2} \mathrm{O}_{2} 100 \mu \mathrm{M}\right)$ treatments, control: PBS. Living cell images were recorded on InCyte3. Figure S14. Alkaline Comet results, scale bar: $200 \mu \mathrm{m}$. Figure S15. TEM images for $20 \mathrm{~h}$ cellular uptake of GQDs in 4T1 cells.

Additional file 2. Time-lapse imaging of 4T1 cells treated with PBS (Control) and GQDs under TME for 24 hours.

Additional file 3. Time-lapse imaging of Pl-stained 4T1 cells treated with PBS (Control), TME, GQDs (100 $\mu \mathrm{g} / \mathrm{ml})$ and GQDs under TME for 24 hours.

Additional file 4. 3D cell model -1 cell: 4T1 cells after $24 \mathrm{~h}$ cellular uptake of GQDs from Z-stack confocal iamges (grey - cell membrane, Dil; Red nuclei, NucRed647; Blue - GQDs).

Additional file 5. 3D cell model -4 cells: 4T1 cells after $24 \mathrm{~h}$ cellular uptake of GQDs from Z-stack confocal images (grey- cell membrane, Dil; Red nuclei, NucRed647; Blue - GQDs).

\section{Acknowledgements}

The authors greatly acknowledge the financial support from ARC Discovery Projects (DP200103587, DP190103881, and FL190100126). The authors acknowledge the use of facilities in the Electron Microscope Unit, Solid State and Elemental Analysis Unit, Spectroscopy Laboratory, NMR Facility, Biomedical Imaging Facility and Flow Cytometry Facility within the Mark Wainwright Analytical Centre (MWAC) at UNSW Sydney. The authors thank Dr.Chenhao Zhang for the assistance with the operation of the Electron Microscope.

\section{Authors' contributions}

The author contributions for this work are as follows: conceptualization: ZG. and LD. Data collections: XW. Formal analysis and investigation: XW and $\mathrm{CH}$. Writing the original draft: XW, ZG, and LD. Funding acquisition: ZG and LD. Supervision and validation: ZG and LD. All authors read and approved the final manuscript.
Availability data and materials

All data in the published article or Additional file 1 are available on request from the authors.

\section{Declarations}

Competing interests

The authors declare no conflict of interest.

Received: 24 June 2021 Accepted: 21 September 2021

Published online: 26 October 2021

\section{References}

1. Kim JY, Park JH. ROS-dependent caspase-9 activation in hypoxic cell death. FEBS Lett. 2003;549:94-8.

2. Radogna F, et al. Cell type-dependent ROS and mitophagy response leads to apoptosis or necroptosis in neuroblastoma. Oncogene. 2016;35:3839-53.

3. Fan J, et al. Bruceine D induces lung cancer cell apoptosis and autophagy via the ROS/MAPK signaling pathway in vitro and in vivo. Cell Death Dis. 2020. https://doi.org/10.1038/s41419-020-2317-3.

4. Du X, et al. Acetoacetate induces hepatocytes apoptosis by the ROS-mediated MAPKs pathway in ketotic cows. J Cell Physiol. 2017:232:3296-308.

5. Sharma $V$, Anderson D, Dhawan A. Zinc oxide nanoparticles induce oxidative DNA damage and ROS-triggered mitochondria mediated apoptosis in human liver cells (HepG2). Apoptosis. 2012;17:852-70.

6. Saleem J, Wang L, Chen C. Carbon-based nanomaterials vfor cancer therapy via targeting tumor microenvironment. Adv Healthc Mater. 2018;7:1-30.

7. López-Lázaro M. Dual role of hydrogen peroxide in cancer: Possible relevance to cancer chemoprevention and therapy. Cancer Lett. 2007;252:1-8

8. Kong N, et al. Ros-mediated selective killing effect of black phosphorus: mechanistic understanding and its guidance for safe biomedical applications. Nano Lett. 2020;20:3943-55.

9. Liu C, et al. Arsenene nanodots with selective killing effects and their low-dose combination with ß-elemene for cancer therapy. Adv Mater. 2021;2102054:2102054

10. Gao L, et al. Intrinsic peroxidase-like activity of ferromagnetic nanoparticles. Nat Nanotechnol. 2007;2:577-83.

11. Pan $\mathrm{X}$, et al. Metal-organic-framework-derived carbon nanostructure augmented sonodynamic cancer therapy. Adv Mater. 2018;30:1-9.

12. Ji $X$, et al. Capturing functional two-dimensional nanosheets from sandwich-structure vermiculite for cancer theranostics. Nat Commun. 2021;12:1-17.

13. Yu L, Hu P, Chen Y. Gas-generating nanoplatforms: material chemistry, multifunctionality, and gas therapy. Adv Mater. 2018;30:1-40.

14. Zhu H, et al. Cobalt nanowire-based multifunctional platform for targeted chemo-photothermal synergistic cancer therapy. Colloids Surfaces B Biointerfaces. 2019;180:401-10.

15. Nappi AJ, Vass E. Hydroxyl radical production by ascorbate and hydrogen peroxide. Neurotox Res. 2000;2:343-55.

16. Qin Q, Liu Y, Li X, Sun T, Xu Y. Enhanced heterogeneous Fenton-like degradation of methylene blue by reduced CuFe2O4. RSC Adv. 2018:8:1071-7.

17. Liu X, Dai L. Carbon-based metal-free catalysts. Nat Rev Mater. 2016. https://doi.org/10.1038/natrevmats.2016.82.

18. Gong K, Du F, Xia Z, Durstock M, Dai L. Nitrogen-doped carbon nanotube arrays with high electrocatalytic activity for oxygen reduction. Science. 2009;323:760-4.

19. Dai L. Carbon-based metal-free catalysts: design and applications. Weinheim: Wiley-VCH Verlag GmbH and Co. KGaA; 2018.

20. Fan $\mathrm{K}$, et al. In vivo guiding nitrogen-doped carbon nanozyme for tumor catalytic therapy. Nat Commun. 2018. https://doi.org/10.1038/ s41467-018-03903-8.

21. Hu C, Dai L. Doping of carbon materials for metal-free electrocatalysis. Adv Mater. 2019;31:1-17. 
22. Yan $D$, et al. Defect chemistry of nonprecious-metal electrocatalysts for oxygen reactions. Adv Mater. 2017;29:1-20.

23. Zhang $L, X u$ Q, Niu J, Xia Z. Role of lattice defects in catalytic activities of graphene clusters for fuel cells. Phys Chem Chem Phys. 2015;17:16733-43.

24. Jiang $Y$, et al. Significant contribution of intrinsic carbon defects to oxygen reduction activity. ACS Catal. 2015;5:6707-12.

25. Hu C, et al. Carbon nanomaterials for energy and biorelated catalysis: recent advances and looking forward. ACS Cent Sci. 2019:5:389-408.

26. Varghese $\mathrm{N}$, et al. Binding of DNA nucleobases and nucleosides with graphene. ChemPhysChem. 2009;10:206-10.

27. Qi L, Pan T, Ou L, Ye Z, Yu C, Bao B, Wu Z, Cao D, Dai L. Biocompatible nucleus-targeted graphene quantum dots for selective killing of cancer cells via DNA damage. Commun Biol. 2021;4(1):1-2.

28. Liu Y, et al. Efficient synthesis and physical properties of novel H-shaped 2,3,7,8-tetraazaanthracene-based conjugated molecules. Chem Commun. 2012;48:4166-8.

29. Liu J, et al. Metal-free efficient photocatalyst for stable visible water splitting via a two-electron pathway. Science. 2015;347:970-4.

30. Li S, et al. Targeted tumour theranostics in mice via carbon quantum dots structurally mimicking large amino acids. Nat Biomed Eng. 2020. https:// doi.org/10.1038/s41551-020-0540-y.

31. Jia Y, Chen J, Yao X. Defect electrocatalytic mechanism: Concept, topological structure and perspective. Mater Chem Front. 2018;2:1250-68.

32. Leonat L, Sbarcea G, Branzoi IV. Cyclic voltammetry for energy levels estimation of organic materials. UPB Sci Bull Ser B Chem Mater Sci. 2013;75:111-8.

33. Cao Z, et al. Biodegradable 2D Fe-Al hydroxide for nanocatalytic tumordynamic therapy with tumor specificity. Adv Sci. 2018. https://doi.org/10. 1002/advs.201801155.

34. Yan X, Jia Y, Yao X. Defects on carbons for electrocatalytic oxygen reduction. Chem Soc Rev. 2018;47:7628-58.

35. Jia Y, et al. Defect graphene as a trifunctional catalyst for electrochemical reactions. Adv Mater. 2016;28:9532-8.

36. Gonzalez DH, Kuang XM, Scott JA, Rocha GO, Paulson SE. Terephthalate probe for hydroxyl radicals: yield of 2-hydroxyterephthalic acid and transition metal interference. Anal Lett. 2018;51:2488-97.

37. Sun H, Gao N, Dong K, Ren J, Qu X. Graphene quantum dots-band-aids used for wound disinfection. ACS Nano. 2014;8:6202-10.

38. Yang B, Ding L, Yao H, Chen Y, Shi J. A metal-organic framework (MOF) fenton nanoagent-enabled nanocatalytic cancer therapy in synergy with autophagy inhibition. Adv Mater. 2020;32:1-12.

39. Kalyanaraman B, Darley-Usmar V, Davies KJ, Dennery PA. Measuring reactive oxygen and nitrogen species with fluorescent probes: challenges and limitations. Bone. 2008;23:1-7.

40. Hao G, Xu ZP, Li L. Manipulating extracellular tumour pH: an effective target for cancer therapy. RSC Adv. 2018;8:22182-92.

41. Phaniendra A, Jestadi DB, Periyasamy L. Free radicals: properties, sources, targets, and their implication in various diseases. Indian J Clin Biochem. 2015;30:11-26.
42. Elefantova K, Lakatos B, Kubickova J, Sulova Z, Breier A. Detection of the mitochondrial membrane potential by the cationic dye JC-1 in 11210 cells with massive overexpression of the plasma membrane $A B C B 1$ drug transporter. Int J Mol Sci. 2018;19:1-14.

43. Yee C, Yang W, Hekimi S. The intrinsic apoptosis pathway mediates the pro-longevity response to mitochondrial ROS in C elegans. Cell. 2014;157:897-909.

44. Fadeel B, Xue D. The ins and outs of phospholipid asymmetry in the plasma membrane: roles in health and disease. Crit Rev Biochem Mol Biol. 2009:44:264-77.

45. Logue SE, Elgendy M, Martin SJ. Expression, purification and use of recombinant annexin $V$ for the detection of apoptotic cells. Nat Protoc. 2009;4:1383-95.

46. Hu K, et al. Marriage of black phosphorus and $\mathrm{Cu} 2+$ as effective photothermal agents for PET-guided combination cancer therapy. Nat Commun. 2020:11:1-15.

47. Spectronic, T. Basic UV-Vis Theory, Concepts and Applications Basic UVVis Theory, Concepts and Applications. 1-28 (2001). Available at: http:// www.du.edu.eg/upFilesCenter/sci/1596861637.pdf.

48. Song Y, Qu K, Zhao C, Ren J, Qu X. Graphene oxide: intrinsic peroxidase catalytic activity and its application to glucose detection. Adv Mater. 2010;22:2206-10.

49. Cornish-Bowden A. One hundred years of Michaelis-Menten kinetics. Perspect Sci. 2015;4:3-9.

50. Clément JL, et al. Assignment of the EPR spectrum of 5,5-dimethyl1-pyrroline N-oxide (DMPO) superoxide spin adduct. J Org Chem. 2005;70:1198-203.

51. Weber RT. Xenon Data Processing Reference. EPR Division Bruker BioSpin Corporation (2012). Available at: http://www.nmrcenter.buffalo.edu/EPR_ Processing.pdf.

52. Tada M, Kohno M, Niwano Y. Alleviation effect of arbutin on oxidative stress generated through tyrosinase reaction with I-tyrosine and I -DOPA. BMC Biochem. 2014;15:1-7.

53. Collins AR. The comet assay for DNA damage and repair: principles, applications, and limitations. Appl Biochem Biotechnol Part B Mol Biotechnol. 2004;26:249-61.

54. Olive PL, Banáth JP. The comet assay: A method to measure DNA damage in individual cells. Nat Protoc. 2006;1:23-9.

55. Lu Y, Liu Y, Yang C. Evaluating in vitro DNA damage using comet assay. J Vis Exp. 2017:2017:2-7.

\section{Publisher's Note}

Springer Nature remains neutral with regard to jurisdictional claims in published maps and institutional affiliations.

Ready to submit your research? Choose BMC and benefit from:

- fast, convenient online submission

- thorough peer review by experienced researchers in your field

- rapid publication on acceptance

- support for research data, including large and complex data types

- gold Open Access which fosters wider collaboration and increased citations

- maximum visibility for your research: over $100 \mathrm{M}$ website views per year

At BMC, research is always in progress.

Learn more biomedcentral.com/submissions 